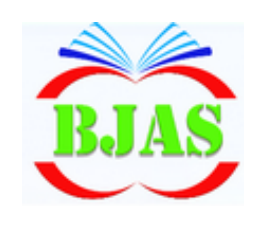

ISSN $1814-5868$
Available online at http://bjas.bajas.edu.iq

https://doi.org/10.37077/25200860.2020.33.1.13

College of Agriculture, University of Basrah

Basrah J. Agric. Sci. 33(1): 172-188, 2020

\section{Basrah Journal of Agricultural Sciences}

E-ISSN: 2520-0860

\title{
Diagnose the Bioactive Compounds in Flaxseed Extract and Its Oil and Use Their Mixture as an Antioxidant
}

\author{
Wasan K. A. Al-Temimi' ${ }^{1}$, Najla H.S. Al- Garory ${ }^{1}$ \& Ali A. Khalaf ${ }^{2}$ \\ ${ }^{1}$ Department of Food Sciences, College of Agriculture, University of Basrah, Iraq \\ ${ }^{2}$ General of Foodstuff Trading, Branch of Basrah' Ministry of Trade, Iraq \\ Corresponding author: e-mail:dr.wasanaltemimi@gmail.com \\ Received 9 April 2020; Accepted 2 June 2020; Available online 27 June 2020
}

\begin{abstract}
The aim of this study is to extract the important antioxidants components of flaxseed in different ways. The Determination of total phenol content, antioxidant activity and percentage of linoleic acid inhibition by DPPH for the components (Lignan, oil, 80 and $100 \%$ ethanolic extract and the deionized water extract). The components of flaxseed oil were identified using GC/MS. The efficiency of the mixture (80\% ethanolic extract and oil) was determined by inhibiting the process of oxidation of linoleic acid during storage periods $(0,7,14$ and 21 days) at laboratory temperature, and the following results were obtained: The yield of lignan, oil, ethanol extract (80 and 100)\% and deionized water were $(0.12,40.52,10.9,9.6$ and 13$) \mathrm{g} .100 \mathrm{~g}^{-1}$ seed respectively, while the total phenolic content of the above components was $(700,1165,3315,2098$ and 483$) \mathrm{mgGAE} 100 \mathrm{~g}^{-1}$,respectively. Flaxseed oil gave the highest antioxidant activity $79.3 \%$ with an inhibition percentage $73.19 \%$, compared with ethanolic extract, lignan and water extract. The diagnosis of GC/MS flaxseed oil showed that the oil was contained in compounds with antioxidant activity, including mono, $\mathrm{di}$ and tri-terpens such as Copaene, Monoterpene, $\beta$ Sesquiphellandrene, Squalene, diethyl phthalate , $\beta$-Sitosterol and Hexadecanoic acid, as well as, the presence of ascorbic acid and gamma tocopherol with good concentrations (8.68 and 2.62)\% respectively. The mixture of $80 \%$ ethanol and oil extract showed an effect in decreasing of peroxide values with an increase of concentration of the added mixture $\left(0.1,0.4\right.$ and $\left.0.10 \mathrm{mg} \cdot \mathrm{mg}^{-1}\right)$. The maximum reduction of the peroxide value at the concentration was $0.6 \mathrm{mg} . \mathrm{mg}^{-1}$, compared with the standard sample during the different durations of storage.

Key word: Flaxseed compounds, Bioactive compound, Total phenol, Antioxidant activity.
\end{abstract}

\section{Introduction}

The Kingdom Plantae has many phytochemicals with therapeutic or nutritional properties that can be an important source of human food and health. Rababah et al. (2004) indicated that plants and some oilseeds are a good source of natural antioxidants, which provide good protection against oxidation of foods systems (Devie et al., 2007; Elizabeth et al., 2007).

Flaxseeds has been known since ancient times and has been used in human food thousands of years ago. It was planted in Mesopotamia about 4000-5200 BC. Flaxseed has become the focus of many researchers 
Al-Temimi et al. / Basrah J. Agric. Sci., 33(1): 172-188, 2020

because they believe it promotes consumer health and disease prevention due to it containing fibre, protein, lignan, unsaturated fatty acids, especially linolenic acid, as well as potassium, flaxseeds are considered nutraceutical as well as functional foods (Mentes et al., 2008). The evolution of food sciences has provided an excellent opportunity to re-evaluate this important food. Food scientists have shown great interest in flaxseed after identifying its content of unsaturated fatty acids, especially linolenic acid, lignan, dietary fibre, etc., which benefit the health and nutrition of the consumer. Scientists at the National Cancer Institute of America showed that flaxseed was one of six sources that deserved special consideration (Basch et al., 2007; Toure \& Xueming, 2010).

Many studies have indicated that flaxseed contains lignan, unique proteins, phenolic acids, flavonoids and tocopheroles, these compounds are bioactive and have anti-oxidant properties. In addition to that they indicated that flaxseed is the richest plant source in the lignan compound, as it has anti-oxidant properties as well as its role in reducing the risk of cancerous tumours breast and prostate (Hosseinian et al., 2006).

Food scientists and food producers have shown great interest in natural phytochemicals , which acts as an antioxidant, such as polyphenols, ascorbic acid and flavonoids.

Therefore, the current study aimed at determining the components of flaxseeds that have an antioxidant activity (Lignan, oil, water extract and alcohol extract with concentration of 80 and $100 \%$ ethanol) and study the effect of the mixture of the most effective ingredients to prolonging duration of storage for sunflower oil.

\section{Materials \& Methods}

Materials

Flaxseeds Linum usitatissimum L. were obtained from the local herbal shop of Basrah Governorate, Iraq.

\section{Lignan extraction}

Followed the method that was described by Richard et al. (1996) with some modification, $25 \mathrm{~g}$ of flaxseed was treated with a mixture of dioxin solvent and ethyl alcohol at a concentration of 1: 1 volume/ volume by mixing 1: 8 weight/volume of flaxseeds: solvent. The mixture was mixed for 4 hours on the magnetic stirrer and it was left for 24 hours with refrigeration. The mixture was filtered using filter paper No. 1. Evaporating solvent by using the rotary evaporator at $40^{\circ} \mathrm{C}$ to obtain the dry lignan compound.

\section{Extraction of Lipids and Phenolic compounds}

Oils were extracted from flaxseed in the manner described by Anwar \& Przybylski (2012). Phenolic compounds were isolated from mixing $20 \mathrm{~g}$ of precipitation with $200 \mathrm{ml}$ of ethyl alcohol (Sharlow Co., Spain) with concentrations of 80 and 100 ethanol using magnetic stirrer for 12 hours at $750 \mathrm{rpm}$ under laboratory conditions. The process of the extraction was repeated twice, isolating the supernatant using filter paper No. 1. The supernatant was concentrated until dried using evaporator rotary at $45^{\circ} \mathrm{C}$.

\section{Water extraction}

Bioactive compounds were extracted from flaxseed according to the method described by (Barthet et al., 2014). 
Al-Temimi et al. / Basrah J. Agric. Sci., 33(1): 172-188, 2020

\section{Yield Determination}

The value of active compounds was calculated by the mathematical equation mentioned by Nur-Syukriah et al. (2014).

$$
\text { Yield } \%=\frac{\text { Final weight }(\mathrm{g}) \times 100}{\text { Initial weight }(\mathrm{g})}
$$

\section{Total Phenol}

The total phenolic concentration of all extracts was estimated by the Folin-Ciocalteau method and described by Velioglu et al. (1998).

\section{Standard Curve}

The total phenols was calculated based on the correlation between the concentration of Gallic acid and the absorption at $725 \mathrm{~nm}$ wavelength using standard Gallic acid solution (0 - 500) $\mu \mathrm{g} . \mathrm{ml}^{-1}$ (Fig. 1). The standard solution of Gallic acid was prepared according to (Velioglu et al., 1998).

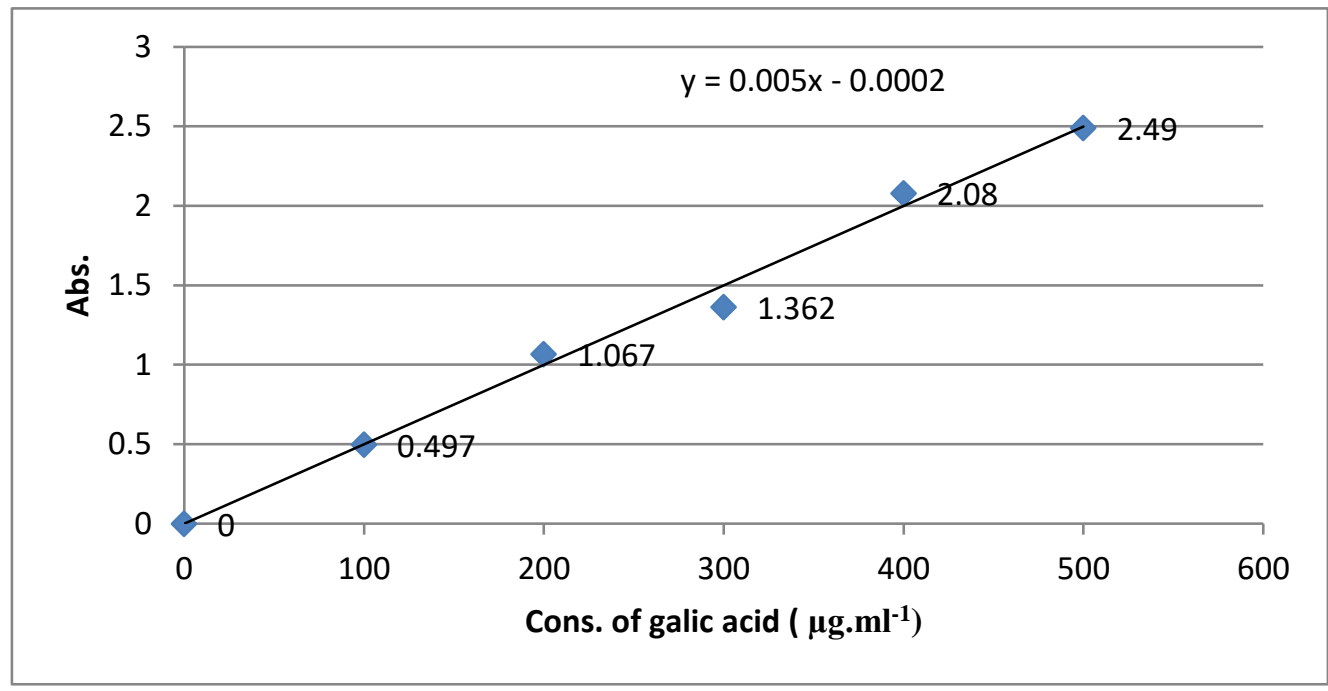

Fig. (1): Standard curve of Gallic acid

\section{Determination of antioxidant activity}

Antioxidant efficacy was measured by method (Amin \& Tan, 2002). $1 \mathrm{ml}$ of $\beta$-carotene $(0.2$ $\mathrm{mg} / \mathrm{ml}$ chloroform) was transformed into a beaker containing $0.02 \mathrm{ml}$ linoleic acid (supplied by Metrya-UK) and $0.2 \mathrm{ml}$ of Tween20. The mixture was preheated at $40^{\circ} \mathrm{C}$ to remove all chloroform. $100 \mathrm{ml}$ of distilled water was immediately added and gradually stirred to form the emulsifier. Preparation of sample $1 \mathrm{mg} \cdot \mathrm{ml}^{-1}$ dissolved in $70 \%$ ethanol. 0.2 $\mathrm{ml}$ of the sample was transferred to different test tubes and added $5 \mathrm{ml}$ of emulsion. The tubes were left in the water bath for two hours at $45^{\circ} \mathrm{C}$. Absorption was measured at $470 \mathrm{~nm}$ every 15 minutes for 120 minutes. The control sample was prepared by mixing $0.2 \mathrm{ml}$ of $70 \%$ ethanol with $5 \mathrm{ml}$ of emulsion.

$$
A A=1-\left(\frac{A t-A 0}{A^{\circ} t-A^{\circ} 0}\right) \times 100
$$

AA $=$ Antioxidant Activity

$A_{t},=$ Absorption of sample at zero time, 
$\mathrm{A}_{0}=$ Absorption control sample at zero time.

$\mathrm{A}^{\circ} \mathrm{t}$, =Absorption of the sample at 120 minutes, $\mathrm{A}^{\circ}{ }_{0}$ Absorption control sample at 120 minutes

\section{The activity of free radicals DPPH}

The free radicals scavenging activity was estimated by Diphenyl-1-picrylhydrazyl (DPPH) as described by Iqbal et al. (2005) with some modification, $5 \mathrm{ml}$ of the DPPH $(0.025$ g. $\mathrm{L}^{-1}$ ) was taken, $1 \mathrm{ml}$ of the sample (prepared $25 \mu \mathrm{g} \cdot \mathrm{ml}^{-1}$ in ethanol) was added to the total of the liquid extract. Absorbance at $515 \mathrm{~nm}$ was measured at wavelength for periods $0,0.5$ and 1, 2, 5 and 10 minutes. The DPPH percentage is calculated according to the equation which mentioned by Egan et al. (1988).

$$
\% \mathrm{DPPH}=\left(\frac{\mathrm{At}}{\mathrm{A} 0}\right) \times 100
$$

$\mathrm{A}_{0}=$ Absorption at $0 \mathrm{~min}$ At $=$ absorption at times $(0,0.5,1,2,5$ and 10) $\mathrm{min}$.

Evaluation of the performance of antioxidants in food systems

Mixture was prepared from $80 \%$ of alcohol extract and flaxseed oil with concentration 1: 1 . After that the mixture was added with concentrations $0,0.1,0.2$ and $0.3 \mathrm{mg} \cdot \mathrm{g}^{-1}$ of sunflower oil free of antioxidants obtained from the State Oil Company, Baghdad, Republic of Iraq. The mixture was incubated at $45^{\circ} \mathrm{C}$. The efficacy of the mixture (oil-alcohol) was measured as an antioxidant by estimating of the peroxide value during durations of storage $(0,7,14$ and 21 days) according to the method mentioned by Egan et al. (1981).

\section{Statistical analysis}

Results were statistically analysed using SPSS (SPSS, 2012), at the probability level $\mathrm{P} \leq 0.05$.

\section{Results \& Discussion}

Fig. (2) shown the yield of the lignan, oil and bioactive compounds extracted from flaxseed with ethanol concentration (80 and 100\%) and deionized water. The yield of components amount was $0.12,40.52,10.9,9.6$ and 13 g.100 $\mathrm{g}^{-1}$ seeds respectively. It was noted that the oil is superior to the rest of the other ingredients used in the study. This increase was due to the flaxseed content of the oil. Ganorkar \& Jain (2013) found that the proportion of oil in flaxseeds was $41 \mathrm{~g} .100 \mathrm{~g}^{-1}$ seeds.

While a study of the chemical composition of flaxseed found that the seed content of oil was $46.22 \%$ (Ingale \& Shrivastava, 2011). It was also noted that the yield of the water extract was superior to the alcohol extract for both concentrations (80 and 100)\%. This increase of water extract yield may be was due to its ability to dissolve some polar compounds as well as to dissolve some carbohydrates (gums, pectin and sugars), and there was some other compound dissolved in water such as soluble fibre and proteins. A number of studies have indicated that flaxseeds contain a good proportion of carbohydrates, fibre and watersoluble proteins. Ganorkar \& Jain (2013) explained that the flaxseed content of carbohydrates 29 g. $100 \mathrm{~g}^{-1}$ seeds and that 10 g. $100 \mathrm{~g} \mathrm{~g}^{-1}$ seeds were water soluble fibre.

Simbalista et al. (2012) pointed out that whole and defatted flaxseed content of soluble fibre ranged from 10.7 to $14.6 \mathrm{~g} .100 \mathrm{~g}^{-1}$, respectively. Herchia et al. (2015) found through a study of chemical composition of flaxseed that the carbohydrate content was $34.1 \%$, while the soluble fibre was $4.3-8.6 \%$.

The reason for the increase in the amount of compounds extracted with ethanol at 80\% concentration as compared to $100 \%$ may be due to increased polarity of the solvent by adding water to it or the chemical nature of the compounds and the solubility of these 
compounds. Simbalista et al. (2012) pointed out that whole and defatted flaxseed content of soluble fibre ranged from 10.7 to $14.6 \mathrm{~g} .100 \mathrm{~g}$ ${ }^{1}$, respectively. Herchia et al. (2015) found through a study of chemical composition of flaxseed that the carbohydrate content was $34.1 \%$, while the soluble fibre was $4.3-8.6 \%$.
The reason for the increase in the amount of compounds extracted with ethanol at $80 \%$ concentration compare with $100 \%$ may be due to increased polarity of the solvent by adding water to it or the chemical nature of the compounds and the solubility of these compounds.

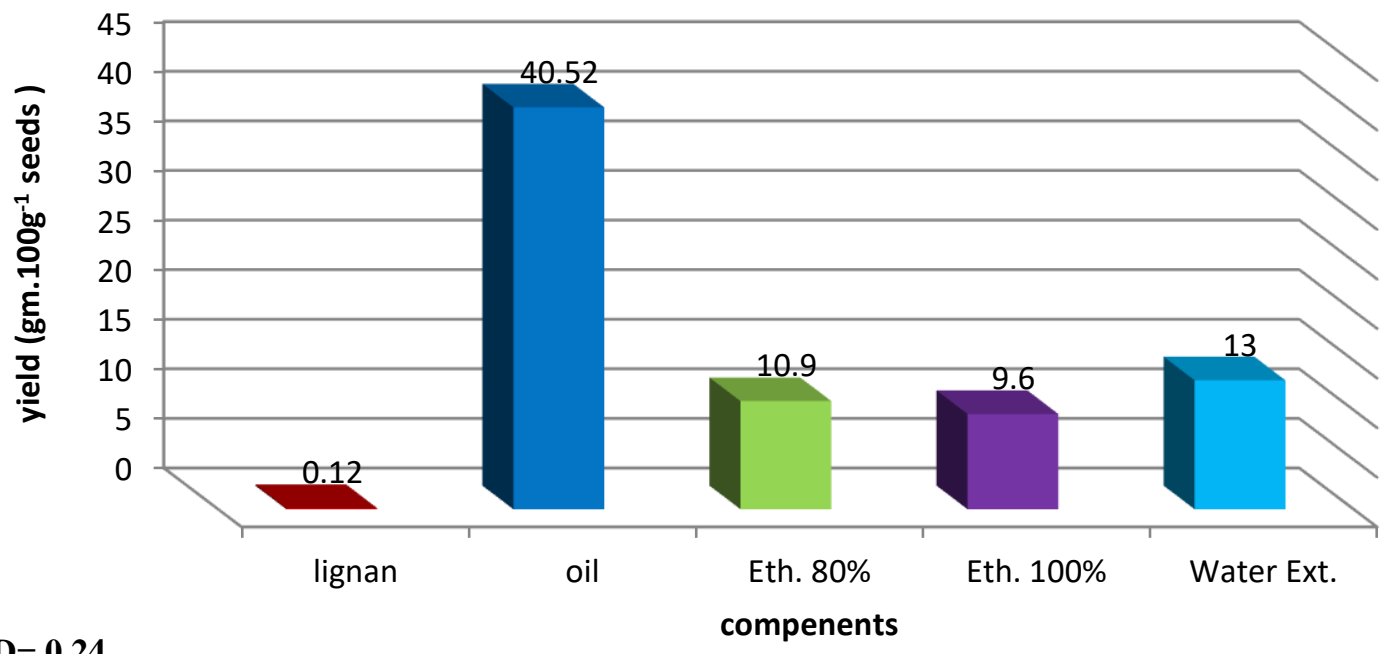

$\mathbf{L S D}=\mathbf{0 . 2 4}$

Fig. (2): Yield of lignan, oil and compounds extracted from flaxseeds using ethanol concentration $(80$ and $100 \%)$ and deionized water.

Many studies have indicated that the added water to ethanol caused an increase in the bioactive compounds, they found that the highest extract of bioactive compounds in flaxseed was at $80 \%$ methanol, while $80 \%$ ethanol gave higher amounts of flavonoids and better antioxidant capacity, they noted that polar solvents showed differences in phenol and flavonoid extraction, that was the strongest in its work as an antioxidant compared to nonpolar solvents (Franco et al., 2008; Anwar \& Przybylski, 2012). It was confirmed by Sultana et al. (2009) that variations in active plant extracts were due to a number of reasons, including the polarity of the solvent, the chemical nature of these compounds as well as their solubility, and that polar solvents such as methanol, ethanol and their mixtures are highly recommended for phenolic compounds. The reason for the decrease in the yield of lignan in flaxseed may be due to its low concentration of lignan in seeds. Thompson et al. (1997) indicated that flaxseeds are the richest in lignan, and the percentage of lignan in flaxseed depends on the type, location and date of cultivation. Hall et al. (2006) found that the content of lignan flaxseed ranged from (330000-370000) $\mu \mathrm{g} .100 \mathrm{~g}^{-1}$ seeds. Ganorkar \& Jain (2013) found that the flaxseed content of the lignan was $0.9-1.9 \%$. 
Al-Temimi et al. / Basrah J. Agric. Sci., 33(1): 172-188, 2020

\section{Determination of total phenols}

Fig. (3) shown the total content of phenols mg. $100 \mathrm{~g}^{-1}$ of flaxseeds for lignan, oil, alcohol extraction at $80 \%$ and $100 \%$ and deionized using the fallen reagent .The total phenolic content in the alcoholic extract $(80 \%)$ was significantly higher at $\mathrm{P} \leq 0.01$ than the other extracts, as it reached to $3315 \mathrm{mg}$ GAE. $100 \mathrm{~g} \mathrm{~g}^{-1}$ seeds. Followed by liquid extraction of flaxseeds using ethanol solvent 100\% concentration of $2098 \mathrm{mg}$ GAE. $100 \mathrm{~g}^{-1}$ seeds, while the total phenols in oil, lignan and deionized water extract of flaxseed were $(1165,700$ and $483 \mathrm{mg})$ GAE $.100 \mathrm{~g}^{-1}$ seeds respectively.

The increase in total phenols in ethanol extracts may be due to the polarity of the solvent or to the chemical nature of the active compounds as well as the solubility of the phenolic compounds in the solvents used. And that the superiority of the concentration of total phenols in the extract treated with solvent $80 \%$ may be due to the addition of water that caused the increase in the polarity of the solvent, which positively affected the amount of phenols total, this is confirmed by Franco et al. (2008). That the addition of water to ethanol caused a significant increase in the value of bioactive compounds. Anwar \& Przybylski (2012) noted that polar solvents such as ethanol and methanol showed significant differences in the extraction of total phenols and flavonoids, these compounds was strongest in their work as antioxidants compared to non-polar solvents, and they showed that total phenol extract from defatted flaxseeds using n-butanol was very low. Also, some studies found that was a high concentration of total phenols in flaxseed oil extracted by using of hexane solvent, they explained that the reason for using hexane solvent in extraction was its chemical nature. The decrease in the total phenolic content in the lignan extract may be due to the decrease in the content of the lignan in the flaxseeds, which

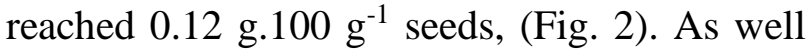
as showed decrease in total phenolic content in the deionized water extract for flaxseed, although the water acts as a polar solvent and caused increase in yield as shown in fig. (2), it may be due to dissolving a number of compounds, especially soluble fibre, proteins and sugars, which affected the total amount of phenols extracted. The results of this study varied with some studies. El-Beltagi et al. (2011) showed that the content of phenolic compounds from flaxseed was $85 \mathrm{mg} \cdot \mathrm{g}^{-1}$, these concentration increased to $96 \mathrm{mg} \cdot \mathrm{g}^{-1}$ after alkaline hydrolysis of flaxseed flour.

Anwar \& Przybylski (2012) found that the total flaxseed content of phenolic compounds (2700, 2020, 1360 and 3260) was GAE.100 $\mathrm{g}^{-1}$ when methanol and ethanol (80 and 100)\% were used in the extraction, respectively. Differences in the amount of phenolic content between our study and other studies may be due to a number of reasons, including the seed class, the extraction methods used, the extraction temperature, the chemical nature of the phenolic and the solvent polarity, this is confirmed by a number of studies (Sultana et al., 2009). 
Al-Temimi et al. / Basrah J. Agric. Sci., 33(1): 172-188, 2020

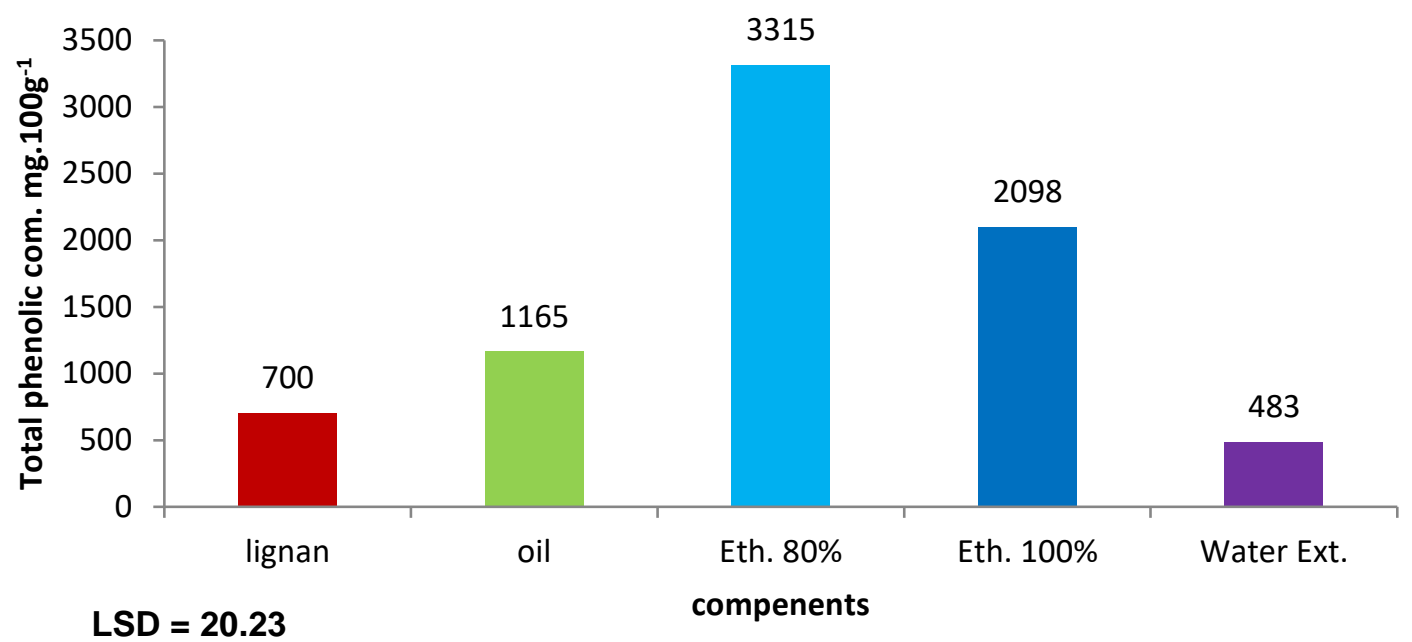

Fig. (3): Total phenolic content of lignan, oil and compounds extracted by using ethanol concentration (80 and $100 \%)$ and deionized water.

\section{DPPH Test and percentage of linoleic acid inhibition}

The antioxidant properties of the flaxseed and its alcoholic and water extracts (lignan, oil, alcohol extract at concentration of $80 \%$ and $100 \%$ and water extract) were measured in 1.1Diphenyl 2-picrylhydrazyl (DPPH) as are shown in fig. (4). The DPPH values for flaxseed oil were significantly higher at $\mathrm{P} \leq 0.01$, as it reached $79.3 \%$ and the rate of inhibition of linoleic acid oxidation was $73.19 \%$. Followed by alcohol extracts at $80 \%$ then $100 \%$ with antioxidant activity amount to (71.24\% and 52.11\%), and with an inhibition ratio of $65.9 \%$ and $43.67 \%$ respectively, while both lignan and water extract gave a lower value from DPPH and an inhibition ratio (35.7 and $21.68 \%)$ and (30.29 and 16.21)\% respectively. The results of antioxidant activity and the percentage of linoleic acid oxidation inhibition of flaxseed compounds and extracts were showed lower than those of BHT compound (95.4\% and 90.2\%) respectively.
The high antioxidant activity values may be attributed to flaxseed oil as it containing a good amount of phenolic compounds as are shown in fig. (3), as well as contain several compounds that will positively affect antioxidant activity values such as ascorbic acid and tocopherols. A number of studies have indicated that flaxseed contains ascorbic acid at a concentration of 0.5 mg. $100 \mathrm{~g}^{-1}$ and tocopherols at a concentration of $569 \mathrm{mg} .100 \mathrm{~g}^{-1}$ included gamma tocopherol, alpha-tocopherol and delta tocopherol with concentrations (552, 7 and $10 \mathrm{mg} .100 \mathrm{~g}^{-1}$ ) respectively (Bernacchia et al., 2014). Herchia et al. (2015) found the content of flaxseed from ascorbic acid was $1.35 \mathrm{mg} .100 \mathrm{~g}^{-1}$ seeds, noting the high acid values by increasing seed germination.

The increase in DPPH for alcohol extract (80\%) compared to the alcohol extracted by (100\%) may be due to increased polarity of the solvent when water was added, Which may help in dissolving more quantities of phenolic compounds, as is noted in fig. (3). A number 
of studies have confirmed that the addition of water to ethanol has enhanced ethanol polarity and has helped dissolve phenolic compounds with antioxidant activity (Franco et al., 2008).

While the lignan and water extract compounds showed a lower in DPPH and the percent inhibition of linoleic acid, that was may be due to the reduction of phenolic compounds total. Barthet et al. (2014) explanted there is a strong relationship between the total phenols and DPPH values in the presence or disappearance of antioxidant activity; these results were confirmed by Slavova-Kazakova $e t$ al. (2016) pointed out that lignan extracted from flaxseed did not have the antioxidant effect, whereas hydrolyzed lignan showed low antioxidant activity. Hosseinian et al. (2006) reported that lignan compounds have the ability to give hydrogen and reduce or inhibit serial reactions to free radical formation.

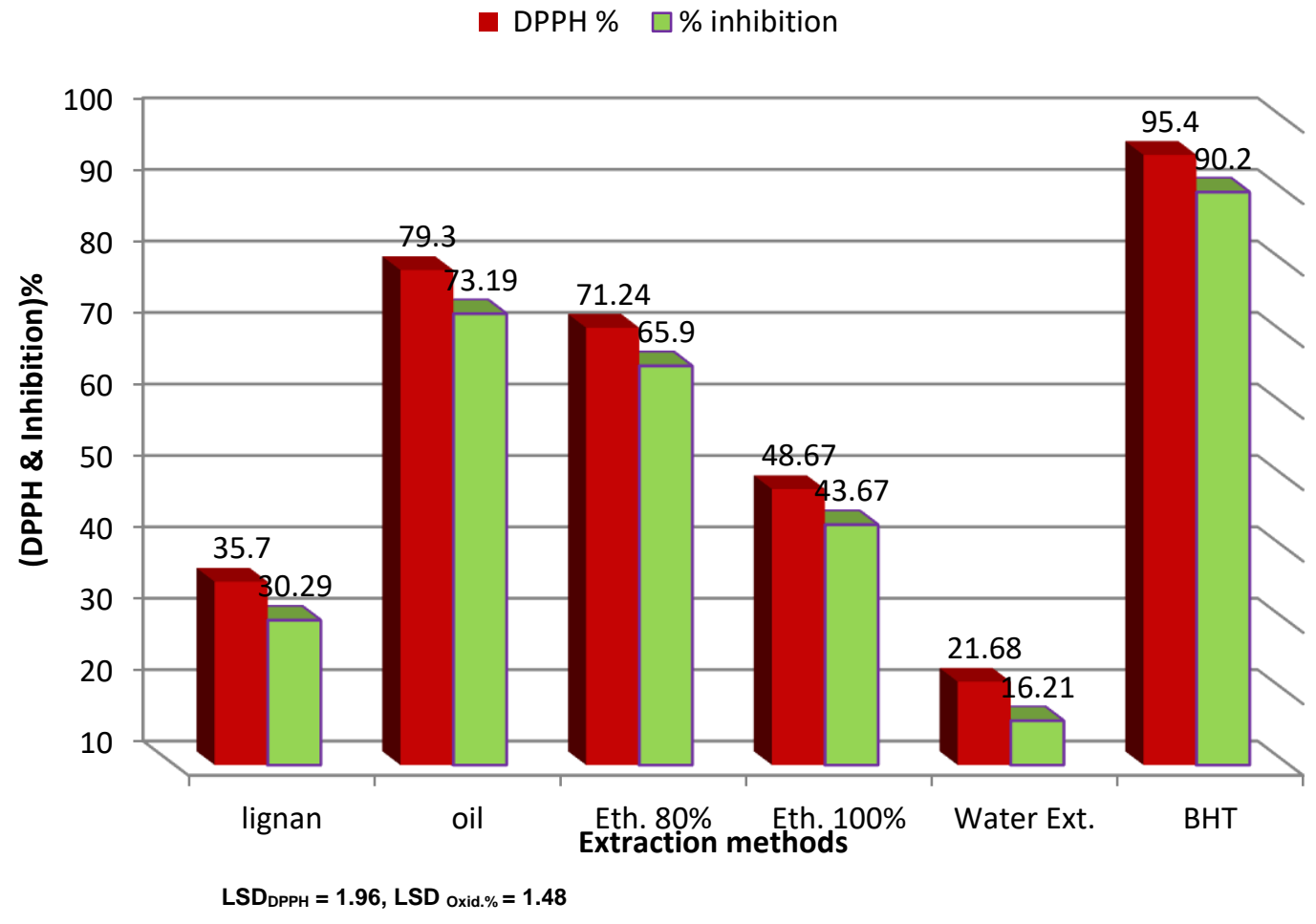

Fig. (4): Percentage of DPPH and oxidation inhibition for flaxseed components and extracts.

While the lignan and water extract compounds showed a lower in DPPH and the percent inhibition of linoleic acid, that was may be due to the reduction of phenolic compounds total. Barthet et al. (2014) explanted there is a strong relationship between the total phenols and DPPH values in the presence or disappearance of antioxidant activity; these results were confirmed by Slavova-Kazakova et al. (2016) pointed out that lignan extracted from flaxseed did not have the antioxidant effect, whereas hydrolyzed lignan showed low antioxidant activity. Hosseinian et al. (2006) reported that lignan compounds have the ability to give hydrogen and reduce or inhibit serial reactions to free radical formation.

The our results of DPPH values and the percent of inhibition linoleic acid were close to a number of studies, Herchia et al. (2015) showed that DPPH values were ranged from 
Al-Temimi et al. / Basrah J. Agric. Sci., 33(1): 172-188, 2020

(40.14 - 52.48) \% to non-germinated flaxseeds. Barthet et al. (2014) found that the DPPH values were ranged from 35.6 to $63.5 \%$ with the superiority of acetone - derived compounds, while the water extract showed DPPH $37.2 \%$.

\section{Diagnosis of GC / MS flax seed oil}

Fig. (5) and table (3) shown the results of the diagnosis of flaxseed oil that were extracted in the cold method by using the hexane solvent. The concentration of the oil components in the gas chromatography technique was estimated. It was observed 30 peaks, where unsaturated fatty acids $69.14 \%$ was superior to linolenic acid by $\quad 65.77 \% \quad(59.3 \% \quad 9.12 .15$ octadecatrienoic acid and $6.47 \%$ Butyl 9, 12, 15 octadecatrienoic) as indicated at the peaks 9 , 13 and 21 respectively. Saturated fatty acids were $11.47 \%$, with octadecanoic acid $\mathrm{C}_{18}$ superiority $6.47 \%$ as indicated in the peak 10 . As it is noted from the table there is the presence of $1.11,13$ heptadecatriene fatty acid, which consists of $\mathrm{C}_{17}$. The results of the GC/MS flaxseed oil analysis showed that there were a number of compounds were particularly effective as antioxidants, as in table (2).

Table (2): Some bioactive components of flaxseed oil.

\begin{tabular}{|c|c|c|}
\hline Name of compound & common name & Concentration $\%$ \\
\hline Copaene & Sesquiterpenes & 0.24 \\
\hline $\begin{array}{l}\text { 1,3-Cyclohexadiene,5-(1,5-dimethyl-4-hexenyl)-2- } \\
\text { methyl-,[S-(R*,S*)] }\end{array}$ & Monoterpene & 0.22 \\
\hline $\begin{array}{l}\text { Cyclohexene,3-(1,5-dimethyl-4-hexenyl)-6-methylene-, } \\
{\left[S-\left(R^{*}, S^{*}\right)\right]-}\end{array}$ & $\beta$-Sesquiphellandrene & 0.17 \\
\hline Diethyl Phthalate & Diethyl Phthalate & 1.85 \\
\hline Ascorbic Acid & Ascorbic Acid & 8.68 \\
\hline $\begin{array}{l}\text { 17-(1,5-Dimethylhexyl)-10,13-dimethyl-4- } \\
\text { vinylhexadecahydrocyclopenta[a]phenanthr }\end{array}$ & $\beta$-Sitosterol & 1.69 \\
\hline $\begin{array}{l}\text { 2,6,10,14,18,22-Tetracosahexaene, } 2,6,10,15,19,23- \\
\text { hexamethyl-,(all-E)- }\end{array}$ & Squalene & 0.32 \\
\hline Gamma.-Tocopherol & Gamma.-Tocopherol & 2.62 \\
\hline
\end{tabular}


Al-Temimi et al. / Basrah J. Agric. Sci., 33(1): 172-188, 2020

CNIVISTSITY COF HASTIRAII

chromatogram of GC- MS

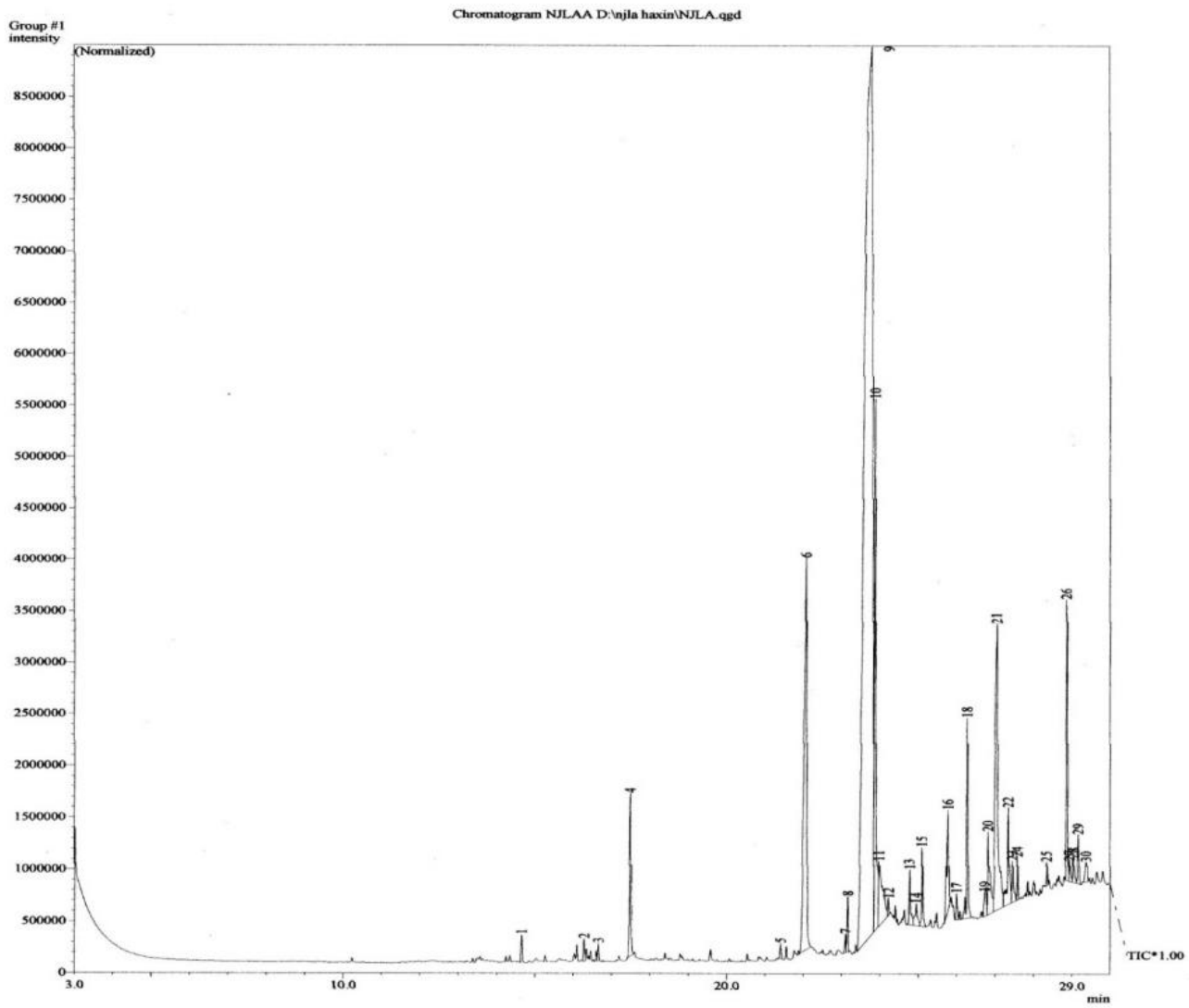

$3 / 25$

Fig.(5): Diagnosis results of GC / MS flax seed oil.

Table (3): Diagnosis results of GC / MS flax seed oil.

\begin{tabular}{|c|c|c|c|c|}
\hline \multicolumn{5}{|r|}{ Peak Report TIC } \\
\hline Peak\# & R.Time & Area & Area\% & Name \\
\hline 1 & 14.657 & 536792 & 0.24 & Copaene \\
\hline 2 & 16.281 & 479714 & 0.22 & 1,3-Cyclohexadiene, 5-(1,5-dimethyl-4-hexenyl)-2-methyl-, $\left[\mathrm{S}-\left(\mathrm{R}^{*}, \mathrm{~S}^{*}\right)\right]-$ \\
\hline 3 & 16.655 & 368113 & 0.17 & Cyclohexene, 3-(1,5-dimethyl-4-hexenyl)-6-methylene-, $\left[\mathrm{S}-\left(\mathrm{R}^{*}, \mathrm{~S}^{*}\right)\right]-$ \\
\hline 4 & 17.489 & 4121549 & 1.85 & Diethyl Phthalate \\
\hline 5 & 21.408 & 305027 & 0.14 & (E,E)-7,11,15-Trimethyl-3-methylene-hexadeca-1,6,10,14-tetraene \\
\hline 6 & 22.073 & 19354337 & 8.68 & 1-(+)-Ascorbic acid 2,6-dihexadecanoate \\
\hline 7 & 23.100 & 340242 & 0.15 & Methyl 12,15-octadecadienoate \\
\hline 8 & 23.155 & 1000913 & 0.45 & 8,11,14-Eicosatrienoic acid, methyl ester \\
\hline 9 & 23.796 & 130710879 & 58.65 & 9,12,15-Octadecatrienoic acid, (Z,Z,Z)- \\
\hline 10 & 23.872 & 14410537 & 6.47 & Octadecanoic acid \\
\hline 11 & 23.975 & 4321858 & 1.94 & 1,E-11,Z-13-Heptadecatriene \\
\hline 12 & 24.217 & 356263 & 0.16 & 1,E-11,Z-13-Octadecatriene \\
\hline 13 & 24.764 & 1447631 & 0.65 & $9,12,15$-Octadecatrienoic acid, $(\mathrm{Z}, \mathrm{Z}, \mathrm{Z})$ \\
\hline 14 & 24.942 & 980417 & 0.44 & cis-13-Eicosenoic acid \\
\hline 15 & 25.093 & 1707461 & 0.77 & Icosanoic anhydride \\
\hline 16 & 25.768 & 3764100 & 1.69 & 17-(1,5-Dimethylhexyl)-10,13-dimethyl-4-vinylhexadecahydrocyclopenta[a]phenanth \\
\hline 17 & 25.990 & 591806 & 0.27 & Hexadecanoic acid, 2-hydroxy-1-(hydroxymethyl)ethyl ester \\
\hline 18 & 26.274 & 4505540 & 2.02 & Dodecanoic acid, dodecyl ester \\
\hline 19 & 26.725 & 1109885 & 0.50 & 3-n-Butylthiophene-1,1-dioxide \\
\hline 20 & 26.819 & 3287629 & 1.48 & Dodecanoic acid, undecyl ester \\
\hline 21 & 27.042 & 14412748 & 6.47 & Butyl 9,12,15-octadecatrienoate \\
\hline 22 & 27.341 & 3448580 & 1.55 & Dodecanoic acid, tetradecyl ester \\
\hline 23 & 27.450 & 1148083 & 0.52 & 13-Docosenamide, $(\mathrm{Z})$ - \\
\hline 24 & 27.578 & 714643 & 0.32 & $2,6,10,14,18,22$-Tetracosahexaene, $2,6,10,15,19,23$-hexamethyl-, (all-E)- \\
\hline 25 & 28.340 & 408014 & 0.18 & Hexadecanoic acid, dodecyl ester \\
\hline 26 & 28.861 & 5836577 & 2.62 & .gamma.-Tocopherol \\
\hline 27 & 28.942 & 542817 & 0.24 & i-Propyl 9,12,15-octadecatrienoate \\
\hline 28 & 29.042 & 669431 & 0.30 & Stigmasta-5,22-dien-3-ol, acetate, (3.beta.)- \\
\hline 29 & 29.167 & 1138190 & 0.51 & Stigmast-5-en-3-ol, oleate \\
\hline 30 & 29.377 & 846117 & 0.38 & 17-(1,5-Dimethylhexyl)-10,13-dimethyl-2,3,4,7,8,9,10,11,12,13,14,15,16,17-tetradeca \\
\hline & & 222865893 & 100.00 & \\
\hline
\end{tabular}


The results of these study were close to that of some researchers. Popa et al. (2012 ) found that the GC/MS flaxseed oil content of saturated fatty acids was $11.01 \%$ distributed (6.58\% palmitic acid and $4.43 \%$ stearic acid). The polyunsaturated fatty acids were $88.97 \%$ divided by $53.21 \%$ linolenic acid, $18.51 \%$ oleic acid and $17.25 \%$ linoleic acid respectively. Another study found the concentration of linolenic acid was $22.8 \mathrm{~g} .100 \mathrm{~g}^{-1}$ while octadecanoic was $1.3 \mathrm{~g} .100 . \mathrm{g}^{-1}$, gamma tocopherol was $522 \mathrm{mg} .100 \mathrm{~g}^{-1}$ and ascorbic acid $0.5 \mathrm{mg} .100 \mathrm{~g}^{-1}$ (Bernacchia et al., 2014)

Evaluation of the performance of antioxidants in food systems
Fig. (5) shown the peroxide values of sunflower oil after adding different concentrations of mixture that contain $(80 \%$ ethanol and flax seed oil) by 1: 1, at concentrations of mixture $(0,0.2,0.4$ and 0.6 $\left.\mathrm{mg} . \mathrm{g}^{-1}\right)$ were used. The change in the peroxide value was measured during the durations of storage $(0,7,14$ and 21$)$ days at laboratory conditions. The obtained results were compared with the values of the peroxide of sunflower oil added to $0.05 \mathrm{mg}$. $\mathrm{g}^{-1} \mathrm{BHT}$ at the same durations. The peroxide value of the control sample was 1.21 meq. $\mathrm{kg}^{-1}$ at 0 day of storage, rising to 27.25 meq. $\mathrm{kg}^{-1}$ at the end of storage period (21 days), of storage period (21 days).

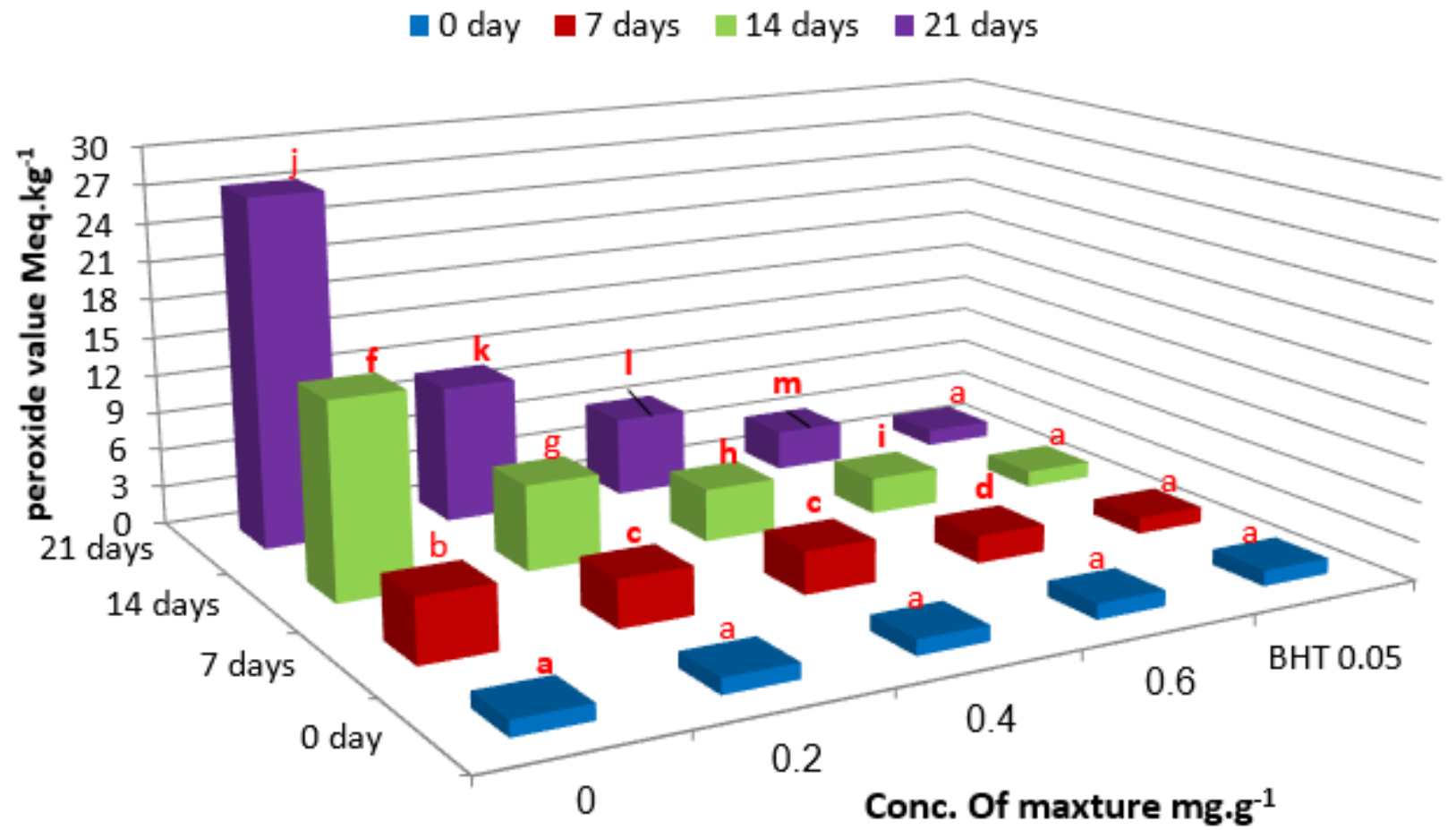

Fig. (5): Determination of the peroxide values of sunflower oil added to different concentrations of mixture (ethane and linseed oil) by 1: 1 and BHT during different storage periods. (The different letters refer to that there are significant differences between the rates at probability $P \leq 0.05$ ). 
while the other concentrations showed a significant decrease $\mathrm{P} \leq 0.05$ in the peroxide values for the other concentrations. A peroxide value for the concentration of 0.2 $\mathrm{mg} \cdot \mathrm{g}^{-1}$ was $1.21 \mathrm{meq} \cdot \mathrm{kg}^{-1}$ at the 0 day of storage, reaching to 10.734 meq. $\mathrm{kg}^{-1}$ at the end concentrations $(0.4$ and 0.6$) \mathrm{mg} \cdot \mathrm{g}^{-1}$ showed the highest increase in peroxide values at the end of storage period (6.197and 3.155) meq. $\mathrm{kg}^{-1}$, respectively. The concentration of BHT added to the sunflower oil showed a slight change in the peroxide values during storage, as it was $1.25,1.27,1.28$ and 1.3 ) for meq. $\mathrm{kg}^{-1}$ for the mentioned periods.

The significant change in the peroxide values of sunflower oil, which has different concentrations of the mixture (alcohol extract: flaxseed oil), may be due to containment of mixture good concentrations of phenolic compounds that possessed bioactivity as shown in fig. (3) and fatty acid hexadecanoic acid ethyl ester, as well as the presence of ascorbic acid and gamma tocopherols with good concentrations (8.68 and $2.62 \%$ ) respectively. Ascorbic acid and gamma tocopherols possessed antioxidant effect and their work as synergistic action, the tocopherols donate the hydrogen atom at the 6-Hydroxyl group to the chroman ring and single oxygen capture; this will produce radical of the tocopherol, with a strong reducing agent such as ascorbic acid, will act to reduce the tocopherol radical and convert it to tocopherol again. This process is called regenerated of tocopherol and thus the action of tocopherol continues as an antioxidant. Moreover, the ascorbic acid played as scavenger or capture for free radicles, single oxygen and metals that caused oxidation in foods systems. Bernacchia et al. (2014) showed that the flaxseed content of gamma tocopherol was $522 \mathrm{mg} .100 \mathrm{~g}^{-1}$ seeds and $0.5 \mathrm{mg} .100 \mathrm{~g}^{-1}$ of ascorbic acid. Ivanova-Petropulos et al. (2015) noted that there were 41 terpenic compounds in sunflower oil, pumpkin seed oil and flaxseed oil. Flaxseed oil ranked third with $47.66 \%$ of total terpenes after sunflower oil pumpkin seed oil. Moreover, the results of the diagnosis showed a betasesquiphellandrene compound. Han et al. (2018) indicated that the effectiveness of ascorbic acid as an antioxidant in oils is higher than its presence in emulsifiers; the reason for that was attributed to the difference in polarization.

A number of studies have shown that copaene is a terpenic compound called sesquiterpenes, which is found naturally in the oils of some plants and has shown antioxidant activity, a study noted that copaene compound showed an inhibition activity for linoleic acid oxidation amounted 80\% (Quintans et al., 2013) .

Ibraheim et al. (2012) explained that 1,3cyclohexadiene, 5- (1,5-dimethyl-4-hexenyl) -2-methyl, [S- $\left.\left(\mathrm{R}^{*}, \mathrm{~S}^{*}\right)\right]$ compound is monoterpene, and it is one of the compounds with antioxidant activity in tea tree oil. Zhao et al. (2010) pointed out that the compound of beta-sesquiphellandrene of antioxidants in turmeric. Arora et al. (2017) reported that cyclohexene, 1.5-dimethyl-4-hexenyl-6methyl-[S- $\left.\left(\mathrm{R}^{*}, \mathrm{~S}^{*}\right)\right]$ is called BetaSesquiphellandrene. It is one of the 
sesquiterpene compounds that found in high concentrations in garlic oil and has antioxidant and cancer effects.

El-Sayed et al. (2015) found that the compound of diethyl hexyl phthalate obtained from $P$. janthinellum had an antioxidant activity amounted $77.99 \%$ at the concentration of $12 \mu \mathrm{g} \cdot \mathrm{ml}^{-1}$. A number of studies have also indicated that the betasitosterol compound is the common name of compound 17- (1, 5-Dimethylhexyl) -10,13dimethyl-4 vinylhexadecahydrocyclopenta [a] phenanthr has an antioxidant effect (Gupta et al., 2011). While Baskar et al. (2012) explained that the compound betasitosterol is a low to moderate antioxidant through its ability to reduce the level of reactive oxygen.

Tyagi \& Agarwal (2017) found that hexadecanoic acid has an antioxidant effect. It was also noted that 2, 6, 10, 14, 18, 22tetracosahexaene, 2, 6, 10, 15, 19, 23hexamethyl-, (all-E) -the peak 24, which common name is squalene, were found in liver oil Shark and some seeds such as grape seeds and flaxseed. Arora et al. (2017) indicated that squalene is a tri-terpene and a natural antioxidant. Dessi et al. (2002) explained that the squalene has an ability to protect linolenic acid, linoleic, aracidone and decosahexanoic acid from oxidation during thermal treatment and ultraviolet radiation.

\section{Conclusion}

The results obtained by GC/MS for the extract of alcohol and flax seed oil have been observed to contain many important compounds that have a positive effect on the preservation of human food and health. This benefits can be increased by combining these compounds (alcohol extract and oil) which lead to inhibition factors causing oxidation. It was concluded that the concentration of $0.6 \mathrm{mg} \cdot \mathrm{g}^{-1}$ at $1: 1$ mixing ratio showed a clear advantage in preserving the oxidation of sunflower oil compared to the standard sample.

\section{Acknowledgements}

Sincere thanks go to the Department of Food Science, College of Agriculture and University of Basrah for helping me complete our research.

\section{Conflict interest}

The authors declare that they have no conflict of interests.

\section{References}

Amin, I. \& Tan, S.H. (2002). Antioxidant activity of selected seaweeds. Malays. J. Nutr., $\quad$ 8: 167-177. http://nutriweb.org.my/mjn/publication/0 8-2/d.pdf.

Anwar, F. \& Przybylski, R. (2012). Effect of solvents extraction on total phenols and antioxidant activity of extracts from flaxseed (Linum usitatissimium L.). Acta Sci. Pol., Technol. Aliment., 11(3): 293301. PMID: 22744950.

Arora, S.S. \& Kumar, G. (2017). Screening and evaluation of bioactive compounds of Cenchrus ciliaris L. by GC-MS analysis. Int. Res. J. Pharm., 8(6): 69-76. https://doi.org/10.7897/2230-8407.08699

Barthet, V.J.; Klensporf-Pawlik, D. \& Przybylski, R. (2014). Antioxidant activity of flaxseed meal components. 
Can. J. Plant Sci., 94(3): 593-602. https://doi.org/10.1139/cjps2013-018

Basch, E.; Bent, S.; Collins, J.; Dacey, C.; Hammerness, P.; Harrison, M.; Smith, M.; Szapary, P.; Ulbricht, C.; Vora, M. \& Weissner, W. (2007). Flaxseed and flaxseed oil (Linum usitatissimum): A review by the natural standard research collaboration. J. Soc. Integr. Oncol., 5(3): 92-105. https://doi.org/10.2310/7200.2007.005

Baskar, A.A.; Al-Numair, K.S.; Gabriel, P.M.; Alsaif, M.A.; Muamar, M.A. \& Ignacimuthu, S. (2012). $\beta$-sitosterol prevents lipid peroxidation and improves antioxidant status and histoarchitecture in rats with 1,2-dimethylhydrazine-induced colon cancer. J. Med. Food, 15(4): 335343. https://doi.org/10.1089/jmf.2011.1780.

Bernacchia, R.; Preti, R. \& Vinci, G. (2014). Chemical composition and health benefits of flaxseed. Austin J. Nutr. Food Sci., $\quad 2(8)$ : 1045-1055. https://www.researchgate.net/publication/ 292963467_Chemical_composition_and_ health_benefits_of_flaxseed.

Dessi, M.A.; Deiana, M.; Day, B.W.; Rosa, A.; Banni, S. \& Corongiu, F.P. (2002). Oxidative stability of polyunsaturated fatty acids: effect of squalene. Eur. J. Lipid Sci. Techn., 104(8): 506-512. https://doi.org/10.1002/14389312(200208)104:8<506::AID-

\section{EJLT506>3.0.CO;2-1}

Devie, R.R.; Jayalekshmy A. \& Arumghan C. (2007). Antioxidant efficacy of phytochemical extracts from defatted rice bran in the bulk oil system. Food Chem.,
104(2): 658-664. https://doi.org/10.1016/j.foodchem.2006. 12.014

Egan, H., Kirk, R.S. \& Sawyer, R. (1981) Pearson's chemical analysis of foods. $8^{\text {th }}$ Edn, Churchill Livingstone, London, New York https://www.scirp.org/(S(i43dyn45teexjx 455qlt3d2q))/reference/ReferencesPapers .aspx?ReferenceID $=1749866$

El-Beltagi, H.S.; Salama, Z.A. \& El-Hariri, D.M. (2011). Evaluation of fatty acids profile and the content of some secondary metabolites in seeds of different flax cultivars, J. Gen. Appl. Plant Physiol., 33(3-4):

187-202. http://www.bio21.bas.bg /ipp/gapbfiles/v33/07_3-4_187-202.pdf.

Elizabeth, N.R.G.; Annete, H.; Francisco, R. G.L.; Javier, F.I.P.; Graciela Z.G. \& Alberto, J.G.I. (2007). Antioxidant and antimutagenic activity of phenolic compounds in three different color groups of common beans cultivars. Food Chem., 103, 521-527. https://doi.org/10.1016/j.foodchem.2006. 08.021 .

El-Sayed, O.H; Asker, M.M.S.; Shash, S.M. \& Hamed, S.R. (2015). Isolation, structure elucidation and biological activity of Di- (2-ethylhexyl) phthalate produced by Penicillium janthinellum 62 . Int. J. Chem. Tech. Res., 8(1): 58-66. https://www.researchgate.net/publication/ 281102694 .

Franco, D.; Sineiroz, J.; Rubilar, M.; Sanchezz, M.; Jerezz, M.; Pinelo, M.; Costoya, N. \& Nunez, M.J. (2008). Polyphenols from Plant Materials: 
Extraction and Antioxidant Power. Elec. J. Environ. Agric. Food Chem., 7(8): 3210-3216.

https://www.researchgate.net/publication/ 228546690_Polyphenols_from_plant_ma terials_Extraction_and_antioxidant_powe r.

Ganorkar, P.M. \& Jain, R.K. (2013). Flaxseed- a nutritional punch. Int. Food Res. J., 20(2): 519-525.

Gupta, R.; Sharma, A.K.; Dobhal, M.P.; Sharma, M.C. \& Gupta, R.S. (2011). Antidiabetic and antioxidant potential of $\beta$-sitosterol in streptozotocin-induced experimental hyperglycemia. J. Diabetes, 3(1): 29-37.

https://doi.org/10.1111/j.1753-

0407.2010.00107.x.

Hall, C.; Tulbek, M.C. \& Xu, Y. (2006).

Flaxseed. Adv. Food Nut. Res., 51: 1-97. https://doi.org/10.1016/S10434526(06)51001-0.

Han, H.; Y1lmaz, H. \& Gulcin, I. (2018). Antioxidant activity of flaxseed (Linum usitatissimum L.) shell and analysis of Its polyphenol contents by LC-MS/MS. Rec. Nat. Prod., 12(4): 397-402. https://doi.org/10.25135/rnp.46.17.09.155

Herchia, W.; Bahashwanb, S.; Sebeia, K.; Ben Salehc, H.; Kallela, H. \& Boukhchina, H. (2015). Effects of germination on chemical composition and antioxidant activity of flaxseed (Linum usitatissimum L) oil. Grasasyaceites, $\quad$ 66(1): 1-8. https://doi.org/10.3989/gya.0463141

Hosseinian, F.S.; Muir, A.D.; Westcott, N.D. \& Krol, E.S. (2006). Antioxidant capacity of flaxseed lignans in two model systems. J. Am. Oil. Chem. Soc., 83: 835-840. https://doi.org/10.1007/s11746006-5034-x

Ibraheim, Z.Z.; Abdel-Mageed, W. M.; Dai, H.; Guo, H.; Zhang, L.;Jaspars, M. (2012). Antimicrobial antioxidant daucane sesquiterpenes from Ferula hermonis Boiss. Phytother Res., 26(4): 579-86. https://doi.org/10.1002/ptr.3609.

Ingale, E. \& Shrivastava, S.K. (2011). Nutritional study of new variety of ground nut (Arachis hypogaea L.) JL-24 seeds. African J. Food Sci., 5(8):490-498. http://www.academicjournals.org/app/we broot/article/article1380017384_Ingale\% 20and\%20Shrivastava.pdf .

Iqbal, S.; Bhanger, M.I. \& Anwar, F. (2005). Antioxidant properties and components of some commercially available varieties of rice bran in Pakistan. Food Chem., 93: 265-272.

https://doi.org/10.1016/j.foodchem.2004. 09.024.

Ivanova-Petropulos, V.; Mitrev, S.; Stafilov, T.; Natalija Markova, N.; Leitner, E.; Lankmayr, E. \& Siegmund, B. (2015). Characterisation of traditional Macedonian edible oils by their fatty acid composition and their volatile compounds. Food Res. Int., 77(3): 506514.

https://doi.org/10.1016/j.foodres.2015.08. 014

Mentes, O.; Bakkalbassi, E. \& Ercan, R. (2008). Effect of the use of ground flaxseed on quality and chemical composition of bread. Food Sci. Technol. Int.,

19:

549-556. 
https://doi.org/10.1177/10820132080971 92

Nur -Syukriah, A.R.; Liza, M.S.; Harisun, Y. \& Fadzillah, A.A.M. (2014). Effect of solvent extraction on antioxidant and antibacterial activities from Quercus infectoria (Manjakani). Int. Food Res. J., 21(3).

Popa, V.; Gruia, A.; Raba, D.; Dumbrava, D.; Moldovan, C.; Bordean, D. \& Mateescu, C. (2012). Fatty acids composition and oil characteristics of linseed (Linum usitatissimum L.) from Romania. J. Agroaliment. Proc. Technol., 18(2):

136-140.

https://www.researchgate.net/publication/ 268205116.

Quintans Jde, S.; Soares, B.M.; Ferraz, R.P.; Oliveira, A.C.; da Silva, T.B.; Menezes, L.R.; Sampaio, M.F.; Prata, A.P.; Moraes, M.O.; Pessoa, C.; Antoniolli, A.R.; Costa, E.V. \& Bezerra, D.P. (2013). Chemical constituents and anticancer effects of the essential oil from leaves of Xylopia laevigata. Planta Med., 79: 123-130. https://doi.org/10.1055/s0032-1328091

Rababah, T.M.; Hettiarachy, N.S. \& Horax, R. (2004). Total phenolics and antioxidant activities of feurgreek, green tea, black tea, grape seed, ginger, rosemary, gotu kola, and ginkgo extracts, vitamin $\mathrm{E}$, and ter-butylhrdroquinone. J. Agric. Food Chem., 52: 5183-5186. https://doi.org/10.1021/jf049645z

Richard, S.E.; Orcheson, L.J.; Seidl, M.M.; Luyengi, L.; Fong, H.H. \& Thompson, L.U. (1996). Dose-dependent of mammalian lignans in rats and vitro from the purified precursor secoisolariciresinal diglucoside in flaxseed. J. Nutr., 126: 2012-2019.

https://doi.org/10.1093/jn/126.8.2012.

Simbalista, R.L.; Frota, K.D.M.G.; Soares, R.A.M. \& Areas, J.A.G. (2012). Effect of storage and processing of Brazilian flaxseed on lipid and lignan contents. J. Ciênc. Technol. Aliment., 32(2): 122143. https://doi.org/10.1590/S010120612012005000037.

Slavova-Kazakova, A.; Karamac, M.; Kancheva, V. \& Amarowicz, R. (2016). Antioxidant activity of flaxseed extracts in lipid systems. Molecules, 21: 17: 1-11. https://doi.org/10.3390/molecules 210100 17.

SPSS. (2012) .Statistical packages of social sciences. Version

(21). https://spss.software.informer.com/21.0/

Sultana, B.; Anwar, F. \& Ashraf, M. (2009). Effect of extraction solvent/technique on the antioxidant activity of selected medicinal plant extracts. Molecules, 14: 2167-2180.

https://doi.org/10.3390/molecules140621 67.

Thompson, L.U.; Rickard, S.E.; Cheung, F.; Kenaschuk, E.O. \& Obermeyer, W.R. (1997). Variability in anticancer lignan levels in flaxseed. Nutr. Cancer, 27: 2630.

https://doi.org/10.1080/01635589709514 497.

Toure, A. \& Xueming, X. (2010). Flaxseed lignans: Sources, biosynthesis, metabolism, antioxidant activity, bioactive components, and health benefit. 
Al-Temimi et al. / Basrah J. Agric. Sci., 33(1): 172-188, 2020

Compr. Rev. Food Sci. Food Saft., 9: 261-269. https://doi.org/10.1111/j.15414337.2009.00105.x

analysis of bioactive constituents in the ethanolic extract of Pistia stratiotes L. and Eichhornia crassipes (Mart.) solms. J. Pharmacogn. Phytochem., 6(1): 195206.

http://www.phytojournal.com/archives/?y ear $=2017 \& \mathrm{vol}=6 \&$ issue $=1 \&$ ArticleId $=10$ 79.

Velioglu, Y.S.; Mazza, G.; Gao, L. \& Oomah, B.D. (1998). Antioxidant activity and total phenolics in selected fruits, vegetables and grain products. J. Agric.
Tyagi, T. \& Agarwal, M. (2017). Phytochemical screening and GC-MS

Food Chem., 64: 4113-4117. https://doi.org/10.1021/jf9801973.

Zhao, J.; Zhang, J.S.; Yang, B.; Lv, G.P. \& Li, S.P. (2010). Free radical scavenging activity and characterization of sesquiterpenoids in four species of curcuma using a TLC bioautography assay and GC-MS analysis. Molecules, 15(11):

7547-7557.

https://doi.org/10.3390/molecules151175 47

\title{
تثخيص المركبات النشطة حيويا في مستخلص بذور الكتان وزيتها واستخدام خليطهما كمضاد للأكسدة
}

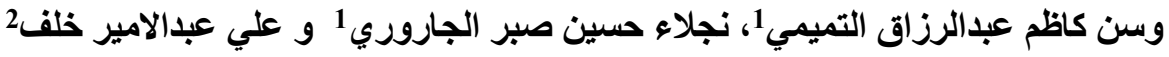

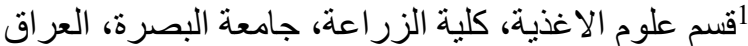

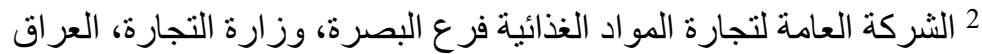

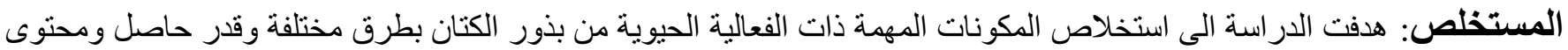

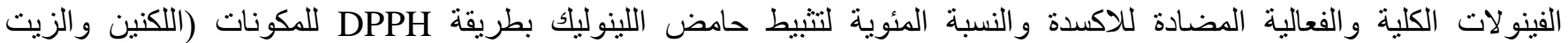

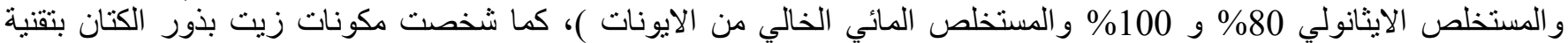

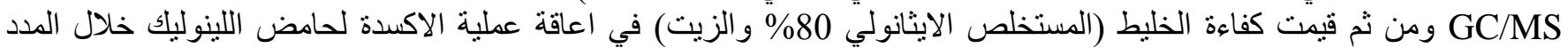

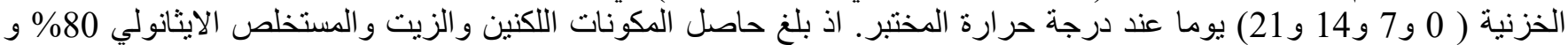

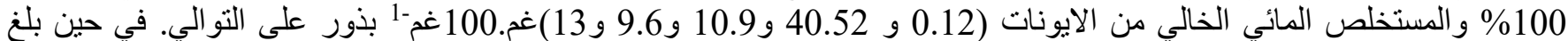

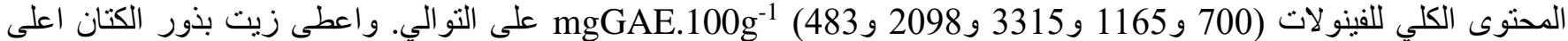

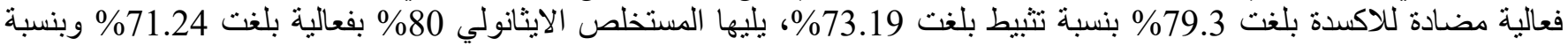

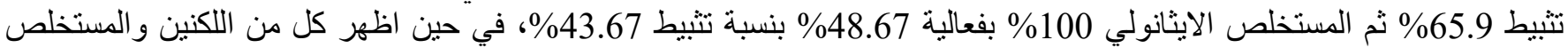

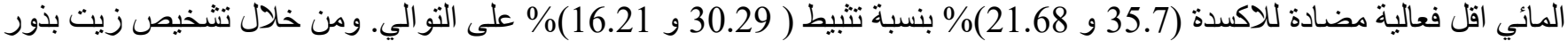
الكتان بتقتية GC/MS لوحظ احتواء الزيت على المركبات ذات الفعالية المضادة للاكسدة شملت المركبات التربينية الاحادية والثنائية

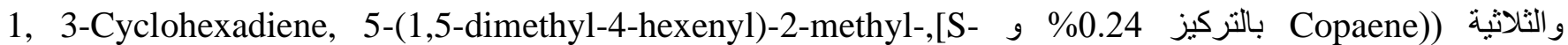

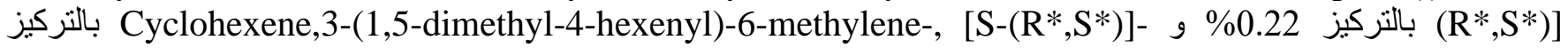

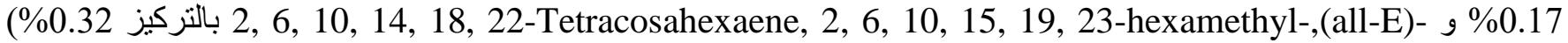

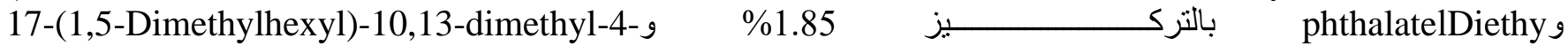

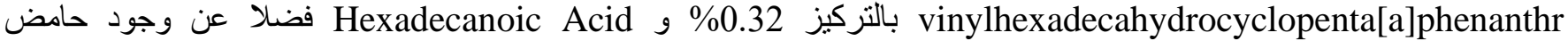
الاسكوربيك والكاما توكوفيرول بتر اكيز جيدة بلغت ( 8.68 و 2.62 )\% على التو الي. كما اظهر خليط المستخلص الايثانولي 80 \%

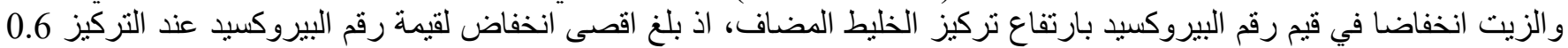

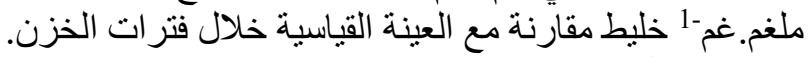
كلمات مفتاحية: مركبات بذور الكتان، المركبات الفعالة حيويا، الفينو لات الكلية، الفعالية المضادة للاكسدة. 